\title{
Pendampingan Masyarakat dalam PengelolaAn Sampah Organik Skala Komunal untuk Mendukung Program Urban Farming
}

\author{
The COMmunity Mentoring in ORGanic Waste Management at Communal Scale to Support \\ THE URBAN FARMING PROGRAM
}

\author{
${ }^{1}$ Reni Amaranti, ${ }^{2}$ Eri A., ${ }^{3}$ M. Satori, ${ }^{4}$ Aswardi N., ${ }^{5}$ Nur Rahman A. \\ 1,2,3,4,5 Fakultas Teknik, Universitas Islam Bandung, Jl. Tamansari No. 1 Bandung 40116 \\ e-mail:1'reniamaranti2709@yahoo.com, ${ }^{2}$ eri_ach@yahoo.co.id, ${ }^{3}$ mohamad_satori@yahoo.com
}

\begin{abstract}
The waste management in urban areas should get treatment from various parties (communities, governments, and businesses) to prevent environmental damage increases. Waste management can be done in the management area of the Rukun Tetangga (RT) and Rukun Warga $(R W)$ level, also the village level. The main problem for the current partner that doesn't spread evenly of knowledge and the capabilities in utilizing waste into something that has economic valuable and the low level of public participation in the program launched by the government especially Kampung Berkebun programs that have been implemented at the level of Rukun Warga $(R W)$. Community Service activity is done by providing assistance to communities to manage organic waste in the local environment (communal scaleRukun Tetangga) program to support the Urban Farming to utilize all potentials and resources that have been owned and has not been utilized properly.
\end{abstract}

Keywords: mentoring, organic waste, urban farming

\begin{abstract}
Abstrak. Penanganan sampah di daerah perkotaan harus mendapatkan penanganan dari berbagai pihak (masyarakat, pemerintah, dan pelaku usaha) untuk mencegah kerusakan lingkungan yang semakin besar. Pengelolaan sampah ini bisa dilakukan dalam area pengelolaan tingkat Rukun Tetangga (RT) maupun setingkat Rukun Warga $(R W)$, bahkan bisa diperluas hingga tingkat Desa/kelurahan. Masalah utama yang yang dihadapi mitra saat ini adalah belum meratanya pengetahuan dan kemampuan masyarakat dalam memanfaatkan sampah menjadi sesuatu yang bernilai ekonomis dan masih rendahnya tingkat partisipasi masyarakat terhadap program yang dilaksanakan pemerintah terutama program Kampung Berkebun yang telah dilaksanakan di tingkat Rukun Warga $(R W)$. Kegiatan Pengabdian Masyarakat ini dilakukan dengan memberikan pendampingan pada masyarakat untuk mengelola sampah organik yang ada di lingkungan setempat (skala komunalRukun Tetangga) untuk mendukung program Urban Farming dengan memanfaatkan semua potensi dan sumber daya yang telah dimiliki dan belum termanfaatkan dengan baik.
\end{abstract}

Kata kunci: pendampingan, sampah organik, urban farming

\section{Pendahuluan}

Kota Bandung merupakan Ibu Kota Provinsi Jawa Barat, memiliki pertumbuhan yang cukup pesat dipicu oleh proses perdagangan, pariwisata, pendidikan, dan pemukiman. Pertumbuhan ekonomi Kota Bandung ini berdampak positif maupun negatif, dan yang paling dirasakan adalah semakin berkurangnya lahan produktif pertanian untuk pengembangan budidaya pertanian. Pertumbuhan penduduk yang tinggi menuntut pemenuhan penyediaan pangan yang meningkat untuk tingkat rumah tangga dan menyebabkan menurunnya kualitas lingkungan hidup. Di sinilah dibutuhkan solusi 
pemecahan dengan mengarah pada pemanfatan teknologi sebagai upaya untuk menciptakan keadaan lingkungan yang sehat, bersih dan sekaligus bisa memberikan keuntungan dari sisi ekonomis.

Konsep Food Oriented Development (FOD) yang saat ini banyak dikenal merupakan konsep pembangunan perkotaan yang mampu menjadikan kota sebagai penyedia pangan bagi warganya secara berkelanjutan. Salah satu perwujudan dari FOD adalah bertani di perkotaan atau biasa disebut urban farming dinilai sebagai hal yang mampu menciptakan ketahanan pangan. Kunci keberhasilan pelaksanaan program Urban Farming adalah menggerakkan sosial agar urban farming bisa berjalan secara massal dengan mengimplementasikan kegiatan Urban Farming mulai di tingkat RT dan RW serta mengembangkan kemampuan agrikultur warganya. Kota Bandung telah menggulirkan Program Kampung Berkebun dengan tujuan untuk pemenuhan kebutuhan pangan segar bagi masyarakat dan untuk perbaikan kualitas lingkungan pemukiman menjadi hijau, nyaman, asri, bersih, dan produktif (Kusnadi, 2014).

Masalah utama yang yang dihadapi mitra saat ini adalah belum meratanya pengetahuan dan kemampuan masyarakat dalam memanfaatkan sampah organik menjadi sesuatu yang bermanfaat dan dapat bernilai tambah bagi keluarga. Selain itu tingkat partisipasi masyarakat terhadap program yang dilaksanakan pemerintah terutama program Kampung Berkebun yang telah dilaksanakan di tingkat Rukun Warga (RW) dinilai masih rendah. Kegiatan Pengabdiam Kepada Masyarakat ini dilakukan untuk berperan dalam menyelesaikan permasalahan tersebut dengan fokus pada identifikasi kebutuhan pelatihan yang dibutuhkan masyarakat untuk mengoptimalkan potensi yang telah ada berkaitan dengan pengolahan sampah organik dan peningkatan partisipasi masyarakat terhadap program kampung berkebun untuk skala Rukun Tetangga. Merumuskan bentuk pengolahan sampah organik skala komunal yang cocok diterapkan di lingkungan masyarakat mitra sesuai dengan potensi yang ada (lahan dan sumber daya lainnya) serta mendampingi masyarakat untuk implementasi program.

Sampah merupakan konsekuensi kehidupan yang sering menimbulkan masalah dan jumlahnya akan semakin meningkat seiring dengan peningkatan jumlah penduduk dan beragam aktivitasnya. Sampah adalah suatu bahan yang terbuang atau dibuang dari sumber hasil aktivitas manusia maupun proses alam yang belum memiliki nilai ekonomis (Ecolink dalam M. Faizal, 2013). Sampah juga dapat berarti sesuatu yang tidak berguna lagi, dibuang oleh pemiliknya atau pemakai semula (Tandjung, Dr. M.Sc. dalam M. Faizal, 2013) atau sumberdaya yang tidak siap pakai (Radyastuti, W. Prof. Ir, dalam izal, 2013). Sampah juga biasa diartikan sebagai materi atau zat, baik yang bersifat organik maupun anorganik yang dihasilkan dari setiap aktivitas manusia baik aktivitas bisa dalam rumah tangga, industri, maupun kegiatan komersial. Sedangkan menurut UU RI Nomor 18 Tahun 2008 Tentang Pengelolaan Sampah pada pasal 1 yaitu sampah adalah sisa kegiatan sehari - hari manusia dan /atau proses alam yang berbentuk padat.

Sampah menjadi persoalan yang cukup serius bagi masyarakat terutama di wilayah perkotaan. Selama ini masyarakat membuang begitu saja sampah ke tempat sampah dan menyerahkan urusan selanjutnya kepada petugas kebersihan dan urusan selesai. Pertambahan jumlah penduduk, perubahan pola konsumsi masyarakat, pertumbuhan ekonomi, perubahan pendapatan, urbanisasi, dan industrialisasi menyebabkan tingginya jumlah timbulan sampah dan menghasilkan sampah yang beragam. Hal serupa diungkapkan dalam UU RI Nomor 18 Tahun 2008 Tentang Pengelolaan Sampah bahwa timbulan sampah diakibatkan oleh pertambahan penduduk 
dan perubahan pola konsumsi masyarakat yang mengakibatkan bertambahnya volume, jenis, dan karakteristik sampah yang semakin beragam.

Berdasarkan UU No.7 Tahun 1996 tentang Pangan, dinyatakan bahwa,"ketahanan pangan adalah terpenuhinya pangan bagi setiap rumah tangga yang tercermin dari ketersediaan pangan yang cukup baik jumlah, mutu, aman, merata dan terjangkau". Berdasarkan hal tersebut setiap anggota masyarakat di kota maupun di desa dapat membantu mewujudkan ketahanan pangan antara lain melalui pemanfaatan pekarangan dengan tanaman sayuran. Pertanian urban adalah praktek budidaya, pemrosesan, dan disribusi bahan pangan di atau sekitar kota. Pertanian urban juga bisa melibatkan peternakan, budidaya perairan, wanatani, dan hortikultura. Dalam arti luas, pertanian urban mendeskripsikan seluruh sistem produksi pangan yang terjadi di perkotaan. FAO mendefinisikan pertanian urban sebagai sebuah industri yang memproduksi, memproses, dan memasarkan produk dan bahan bakar nabati, terutama dalam menanggapi permintaan harian konsumen di dalam perkotaan, yang menerapkan metode produksi intensif, memanfaatkan dan mendaur ulang sumber daya dan limbah perkotaan untuk menghasilkan beragam tanaman dan hewan ternak. Definisi yang diberikan Council on Agriculture, Science and Technology (CAST) mencakup aspek kesehatan lingkungan, remediasi, dan rekreasi. Kebijakan di berbagai kota juga memasukkan aspek keindahan kota dan kelayakan penggunaan tata ruang yang berkelanjutan dalam menerapkan pertanian urban.

Perbedaan antara pertanian urban dan non-urban bisa cukup besar, dan tantangan yang ada pada pertanian urban bisa disebut sebagai kekuatan yang dimiliki. Variasi kondisi sosio-ekonomi perkotaan, budaya, hingga geografi, iklim, dan luas lahan menimbulkan berbagai inovasi dan kebijakan pemerintahan setempat. Diversitas yang membedakan antara satu kota dan kota lain mampu menciptakan keunikan tersendiri. Pertanian ini pun menimbulkan berbagai gerakan lokal seperti "foodies", "locavores", "organic growers" dan sebagainya yang berfungsi sebagai sarana berbagi informasi dan fasilitas jual beli produk setempat, sehingga mendatangkan penghasilan, mengurangi risiko pestisida dan bahan kimia berlebih dalam konsumsi masyarakat, hingga meningkatkan ketahanan pangan. Karena pertanian urban dikatakan memperpendek jarak antara produsen dan konsumen sehingga bahan pengawet dan proses tambahan tidak dibutuhkan. Hal ini membuat konsumen mendapatkan jaminan bahan pangan yang didapatkan begitu segar.

\section{Metode Pelaksanaan}

Berdasarkan analisis pada potensi, sumber daya yang dimiliki, permasalahan utama yang terjadi serta target luaran, maka solusi yang ditawarkan adalah memberikan pelatihan tentang pengolahan sampah organik untuk skala komunal (pada kegiatan PKM ini dimulai dari skala RT) dan pelatihan berkebun (skala kecil dan sederhana) terhadap masyarakat mitra serta melakukan pendampingan untuk mempraktekkan hasil pelatihan, membangun tempat pengolahan sampah organik skala RT, serta uji coba implementasi urban farming untuk skala RT. 


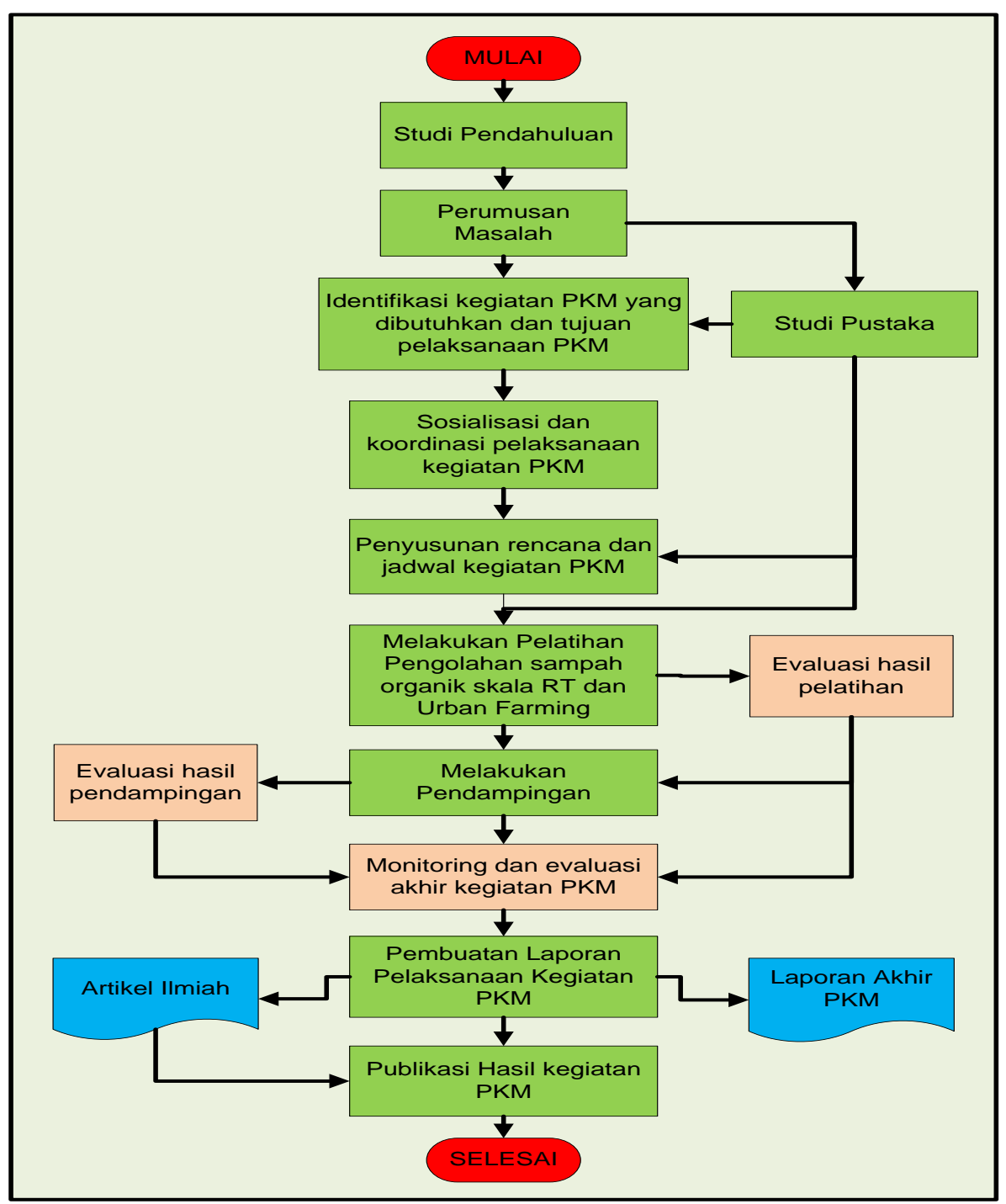

Gambar 1 Tahapan Pelaksanaan Pengabdian Kepada Masyarakat

\section{Hasil dan Pembahasan}

Pada tahap awal dilakukan studi pendahuluan mencakup identifikasi lebih lengkap mengenai kondisi sosio ekonomi masyarakat mitra serta melakukan sosialisasi pelaksanaan program pengabdian masyarakat yang akan dilakukan di lokasi mitra. Kegiatan sosialisasi dilakukan dengan memanfaatkan kegiatan-kegiatan di lingkungan masyarakat mitra seperti kegiatan arisan PKK RT, kegiatan pengajian ibu-ibu warga RT, serta kegiatan pertemuan insidental yang melibatkan masyarakat. Selain itu juga, kegiatan sosialisasi dilakukan pada pengurus RT (Ketua RT dan beberapa pengurus RT). Pada tahap ini juga ditentukan koordinator dalam pelaksanaan PKM untuk memudahkan Tim Pelaksana PKM berkomunikasi mengenai pelaksanaan kegiatan PKM yaitu koordinator pelaksanaan penyiapan lahan untuk Urban Farming, koordinator kegiatan urban farming, serta koordinator pelaksanaan pelatihan.

Tahap selanjutnya adalah menyusun rencana dan jadwal pelaksanaan kegiatan berdasarkan kesepakatan dengan koordinator lapangan, pengurus RT, dan pengurus PKK dan menyusun materi dan metode pelatihan yang akan diberikan kepada masyarakat mitra. 


\section{Melaksanakan Pelatihan}

Jenis pelatihan yang diberikan kepada masyarakat mitra terdiri dari tiga pelatihan, yaitu pelatihan bagaimana memilah sampah dengan benar, pelatihan mengenai pengolahan sampah organik menjadi kompos, serta pelatihan bercocok tanam dengan memanfaatkan lahan di sekitar rumah. Pelatihan untuk memilah sampah dilakukan hanya mengulang kembali pada setiap kegiatan arisan ibu-ibu PKK sedangkan kegiatan pelatihan untuk pembuatan kompos dan urban farming dilakukan secara bersamaan pada waktu yang disepakati bersama. Materi yang disampaikan adalah Pengelolaan sampah skala komunal dan pembuatan kompos dengan bata terawang dan materi budidaya tanaman sayuran di perkotaan.
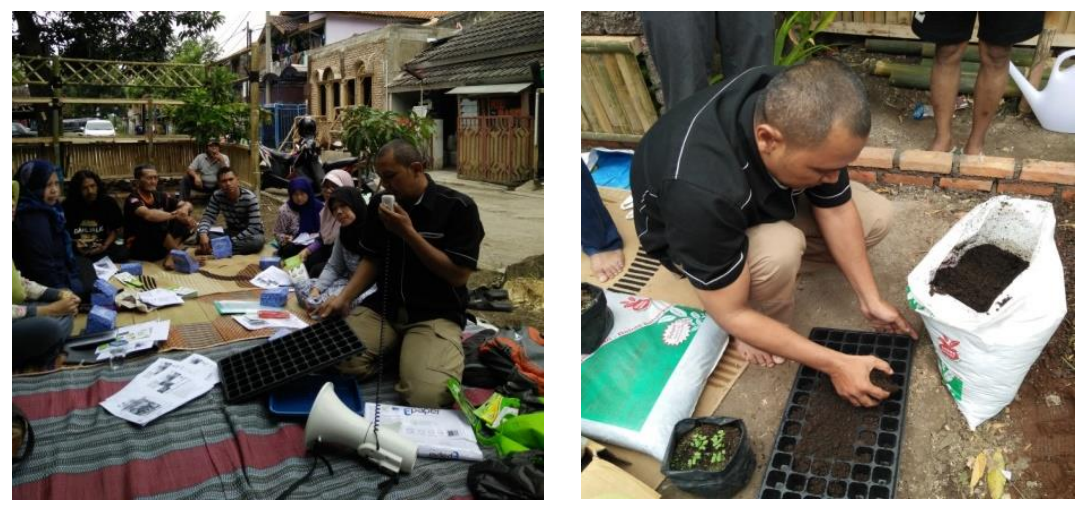

Gambar 2 Pemberian materi dan praktek Urban Farming
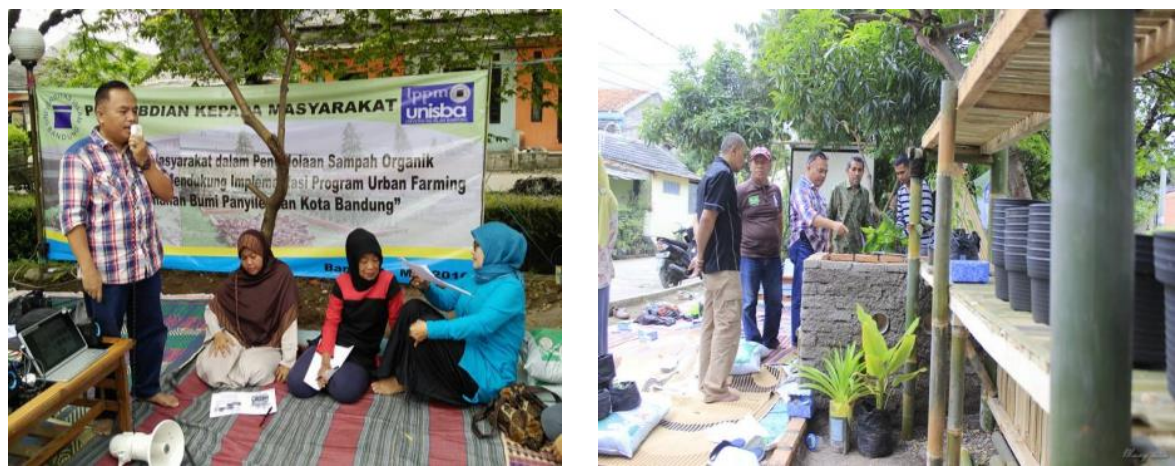

Gambar 3 Penyampaian materi Pengelolaan sampah organik dan praktek pembuatan kompos dengan bata terawang
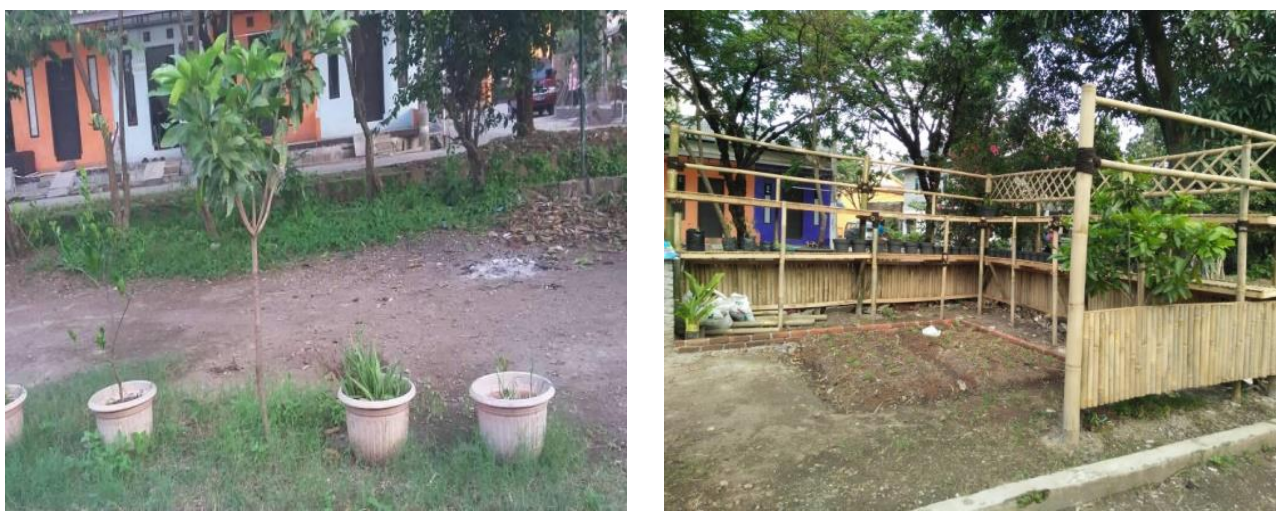
Gambar 4 Kondisi lahan sebelum dan setelah program PKM

\section{Melaksanakan pendampingan pemanfaatan sarana urban farming yang telah dibuat}

Kegiatan yang dilakukan setelah melaksanakan pelatihan adalah melakukan pendampingan kepada masyarakat untuk memanfaatkan fasilitas yang telah dibuat untuk urban farming dan untuk pembuatan kompos organik.

\section{Implementasi konsep Pendampingan}

Kegiatan PKM yang dilakukan pada tahun 2016 ini merupakan kegiatan pendampingan masyarakat dalam pengelolaan sampah organik skala komunal. Dalam kegiatan PKM ini masyarakat mitra diajak untuk melakukan kegiatan yang produktif dengan memanfaatkan potensi dan kekuatan yang ada di masyarakat. Kata pendampingan sendiri dapat dipahami sebagai kegiatan pemberdayaan masyarakat dengan menempatkan tenaga pendamping sebagai fasilitator, komunikator, motivator dan dinamisator. Pada dasarnya, pendampingan merupakan upaya untuk menyertakan masyarakat dalam mengembangkan berbagai potensi sehingga mampu mencapai kualitas kehidupan yang lebih baik. Selain itu diarahkan untuk memfasilitasi proses pengambilan keputusan yang terkait dengan kebutuhan masyarakat, membangun kemampuan dalam meningkatkan pendapatan, melaksanakan usaha yang berskala bisnis serta mengembangkan perencanaan dan pelaksanaan kegiatan partisipatif.

Prinsip-prinsip pendampingan dalam upaya pemberdayaan masyarakat meliputi :

[1]. Prinsip Spasial Lokal. Penguasaan dan pemahaman terhadap ruang, kondisi, potensi dan bahasa lokal dalam pemberdayaan masyarakat.

[2]. Prinsip Berkelompok. Kelompok tumbuh dari, oleh dan untuk kepentingan masyarakat. Selain dengan anggota kelompoknya sendiri, kerjasama juga dikembangkan antara kelompok dan mitra kerja lainnya agar usaha mereka berkembang, meningkatkan pendapatan dan kesejahteraan serta mampu membentuk kelembagaan ekonomi.

[3]. Prinsip Keberlanjutan. Seluruh kegiatan pengembangan diorientasikan pada terciptanya sistem dan mekanisme yang mendukung pemberdayaan masyarakat secara berkelanjutan. Berbagai kegiatan yang dilakukan merupakan kegiatan yang memiliki potensi berlanjut di kemudian hari.

[4]. Prinsip Kemandirian. Masyarakat diberi motivasi dan dorongan untuk berusaha atas dasar kemauan dan kemampuan mereka sendiri dan tidak selalu tergantung pada bantuan dari luar.

[5]. Prinsip Kesatuan Keluarga. Masyarakat tumbuh dan berkembang sebagai satu kesatuan keluarga yang utuh. Kepala keluarga beserta anggota keluarganya merupakan pemacu dan pemicu kemajuan usaha. Prinsip ini menuntut para pendamping untuk memberdayakan seluruh anggota keluarga masyarakat berperan serta dalam meningkatkan pendapatan dan kesejahteraan.

[6]. Prinsip Belajar Menemukan Sendiri. Kelompok dalam masyarakat tumbuh dan berkembang atas dasar kemauan dan kemampuan mereka untuk belajar menemukan sendiri apa yang mereka butuhkan dan apa yang akan mereka kembangkan, termasuk upaya untuk mengubah penghidupan dan kehidupannya.

Kegiatan PKM ini mengambil prinsip kemandirian, keberlanjutan, berkelompok, dan prinsip belajar menemukan sendiri. Tim PKM berusaha untuk mendampingi masyarakat mitra dalam melakukan seluruh rangkaian kegiatan PKM yang nantinya diharapkan masyarakat mitra dapat melanjutkan kegiatan pengolahan sampah organik 
dan urban farming secara mandiri atau berkelompok serta dapat berinovasi untuk pengembangan kegiatan agar dampaknya dapat lebih luas.

Seperti halnya pada program pendampingan masyarakat yang biasa dilakukan, tim pelaksanan PKM memiliki tiga peranan, yaitu sebagai orang yang berperan memberikan berbagai masukan dan pertimbangan yang diperlukan oleh kelompok dalam menghadapi masalah (penasehat kelompok), memberikan berbagai kemampuan dasar yang diperlukan oleh masyarakat mitra seperti mengelola rapat, pembukuan, administrasi, memecahkan masalah, mengambil keputusan dan sebagainya (sebagai Trainer Participatoris), dan sebagai penghubung (Link Person) masyarakat dengan lembaga-lembaga yang terkait (stakeholder) dan diperlukan bagi pengembangan kelompok.

\section{Monitoring dan evaluasi}

Kegiatan monitoring dan evaluasi dilaksanakan untuk implementasi hasil pelatihan yang telah masyarakat terima serta mengetahui partisipasi masyarakat dalam kegiatan PKM yang diusulkan. Pada evaluasi ini juga diidentifikasi kebutuhankebutuhan dan permasalahan yang timbul pada saat pendampingan dilakukan. Evaluasi ini dilakukan pada periode terakhir masa PKM bersamaan dengan pembuatan laporan akhir pelaksanaan PKM. Berikut hasil kegiatan evaluasi dan monitoring yang dilakukan

[1]. Keterlibatan masyarakat mitra pada kegiatan PKM yang dilakukan terutama pada kegiatan pendampingan dinilai masih kurang dan belum sesuai dengan target yang ditetapkan oleh tim. Beberapa orang anggota PKK yang biasa aktif, pada kegiatan PKM ini tidak dapat terlibat penuh karena kesibukan yang bertambah (kegiatan pribadi maupun kegiatan PKK di tingkat RW atau kelurahan)

[2]. Pemanfaatan komposter bata terawang belum maksimal karena sampah yang ditampung di komposter masih kurang dan instalasi komposter bata terawang yang masih perlu diperbaiki.

[3]. Perlakuan terhadap sampah kering atau sampah anorganik sebagian besar masih dibuang langsung dalam tempat terpisah atau diberikan kepada pemulung atau tukang rongsokan yang sering mengambil sampah di lingkungan masyarakat mitra.

[4]. Untuk kegiatan berkebun, sekitar $40 \%$ masyarakat mitra telah melakukan kegiatan berkebun di halaman rumah masing-masing dengan berbagai cara dan media. Secara umum kegiatan berkebun yang dilakukan masih bersifat seadanya dan tidak ditangani dengan sungguh-sungguh. Selain itu, sebagian besar masyarakat mengeluhkan kurangnya pengetahuan mereka dalam merawat tanaman dan menangani hama tanaman sehingga hasil panen tanaman tidak memuaskan atau bahkan tanaman mati.

Hasil evaluasi secara umum menunjukkan bahwa kegiatan yang dilakukan telah memberikan contoh kepada masyarakat mitra dalam menangani sampah organik skala komunal (dalam hal ini skala RT). Masih rendahnya ketertarikan masyarakat mitra untuk turut serta dalam kegiatan urban farming di lahan yang telah disediakan (sekitar 25\% dari total 45 keluarga di RT 01) menjadi tantangan tersendiri bagi Tim Pelaksana PKM dalam merumuskan tindakan perbaikan untuk keberhasilan yang lebih besar dari PKM yang dilakukan. Tim Pelaksana menyadari bahwa mengubah perilaku masyarakat mitra tidak semudah membalikkan telapak tangan, perlu usaha yang besar dan kontinyu atau berkelanjutan agar lebih banyak lagi masyarakat mitra yang tertarik untuk terlibat dalam kegiatan urban farming dan dalam kegiatan pemanfaatan sampah organik untuk dijadikan kompos. Tim pelaksana dalam beberapa bulan ke depan akan tetap melaksanakan pendekatan dan pendampingan masyarakat agar tujuan PKM dapat 
tercapai. Beberapa hal yang dianggap perlu dilakukan dan diusulkan juga oleh masyarakat mitra untuk dilakukan adalah :

[1]. Membuat satu kegiatan untuk melatih masyarakat mitra mengolah sampah kering atau anorganik yang selama ini telah mereka pilah. Tim PKM menerjemahkan usulan masyarakat ini menjadi kegiatan inisiasi pembentukan bank sampah.

[2]. Membuat kegiatan pelatihan dan pendampingan lanjutan mengenai cara bercocok tanam atau berkebun termasuk berkebun dengan metode hidroponik.

[3]. Melakukan kegiatan berkebun dengan skala lebih besar dan penataan lingkungan agar dampak kegiatan PKM dapat lebih besar juga.

\section{Kesimpulan}

Pendampingan masyarakat dalam mengelola sampah organik merupakan kegiatan yang memerlukan kecermatan membaca situasi dan menentukan strategi pelaksanan kegiatan yang tepat sehingga tujuan dapat dicapai secara optimal. Beberapa kendala yang dihadapi tidak semestinya menghalangi proses. Kendala-kendala yang dihadapi diantaranya adalah tingkat partisipasi warga mitra dalam kegiatan pelatihan dikarenakan berbagai alasan. Hal ini akan berdampak pada pencapaian tujuan PKM. Pembuatan rencana pelaksanaan kegiatan PKM yang akurat dapat meminimasi bias dalam pelaksanaan PKM ini.

Peran tim pelaksana PKM sepanjang kegiatan tidak hanya mendampingi masyarakat mitra dalam melakukan program, akan tetapi juga berperan sebagai trainer yang mengajarkan masyarakat mitra mengenai cara mengelola sampah organik, mendampingi masyarakat untuk melakukan kegiatan bercocok tanam walaupun sebagian besar rumah di masyarakat mitra tidak memiliki tempat yang cukup untuk melakukan urban farming. Sekitar $40 \%$ masyarakat mitra telah melakukan kegiatan yang dikatakan Urban Farming di rumah masing-masing sedangkan jumlah masyrakat yang ikut terjun dalam pengolahan sampai organik skala komunal sesuai PKM ini hanya sekitar $25 \%$ atau sekitar 12 orang.

Selanjutnya disarankan untuk mengubah pola monitoring dan evaluasi yang dilakukan sehingga warga menjadi nyaman dan tidak merasa digurui dan sedang dinilai. Kegiatan selanjutnya disarankan untuk menggarap sampah anorganik secara tepat dan akan bernilai tambah kepada masyarakat atau tim pelaksana PKM.

\section{Ucapan Terima Kasih}

\section{Daftar pustaka}

Anik Krismawati dan Rika Asnita, 2011, Pupuk Organik dari Limbah Organik Rumah Tangga, SinarTani-Agroinovasi, Badan Litbang Pertanian Jawa Timur, Edisi 3-9 Agustus 2011 Nomor 3417 Tahun XLI

Daniel Hoornweg dan Paul Munro-Faure, 2008, Urban Agriculture For Sustainable Poverty Allevation and Food Security. www.fao.org/fileadmin/templates/FCIT/PDF/UPA_WBpaper_final_Oktober_2008.pdf

Faizah, 2008, Pengelolaan Sampah Rumah Tangga Berbasis Masyarakat (Studi Kasus di Kota Yogyakarta), Tesis, Program Magister Ilmu Lingkungan Program Pasca Sarjana Universitas Diponegoro, Semarang.

Kusnadi, 2014, Dinas Pertanian dan Ketahanan Pangan Kota Bandung : "Kampung Berkebun Kota Bandung”, rilis 17 Juni 2014, 
http://www.tataruangindonesia.com/fullpost/pertanian/

1403019054/dinas pertanian dan ketahanan_pangan.html, akses tanggal 29 November 2015. M. Faisal Matenggomena, 2013, Pemanfaatan Sampah Rumah Tangga Untuk Budidaya Tanaman Sayuran Organik di Pekarangan Rumah, SinarTani-Agroinovasi, Badan Litbang Pertanian Jawa Timur,Edisi 17-23 April 2013 Nomor 3503 Tahun XLIII.

Yeti Marleni, Rohidin Mersyah, dan Bieng Brata, 2012, Strategi Pengelolaan Sampah

Rumah Tangga di Kelurahan Kota Medan Kecamatan Kota Manna Kabupaten Bengkulu Selatan, Naturalis-Jurnal Penelitian Pengelolaan Sumber Daya Alam dan Lingkungan, Volume 1 Nomor 1 Juni 2012, ISSN 23026715.

http://www.fao.org/ag/agn/nutrition/household / garden.stm

http://caraberkebun.com/cara_cerdas_berkebun_di_lahan_sempit/

http://id.wikipedia.org/wiki/pertanian_urban

http://www.foodsecinfoaction.org

http://greenblue-phinisi.blogspot.co.id/2009/06/pendampingan-dalam-pemberdayaan.html 